\title{
Review
}

\section{A Review of Mammarenaviruses and Rodent Reservoirs in the Americas}

\author{
Gloria Tapia-Ramírez, ${ }^{1}$ Consuelo Lorenzo, ${ }^{1}$ Darío Navarrete, ${ }^{2}$ Arturo Carrillo-Reyes, ${ }^{3}$ \\ Óscar Retana, ${ }^{4}$ and Rocío Carrasco-Hernández ${ }^{5}$ \\ ${ }^{1}$ Departamento de Conservación de la Biodiversidad, El Colegio de La Frontera Sur, Periférico Sur S/N María Auxiliadora, 29290 San Cristóbal de Las \\ Casas, Chiapas, Mexico \\ ${ }^{2}$ Departamento de Observación de la Tierra, Atmósfera y Océano, El Colegio de La Frontera Sur, Periférico Sur S/N María Auxiliadora, 29290 San \\ Cristóbal de Las Casas, Chiapas, Mexico \\ ${ }^{3}$ Facultad de Ingeniería, Universidad de Ciencias y Artes de Chiapas, Av 1a. Sur Pte 1460, C.P., 29000 Tuxtla Gutiérrez, Chiapas, Mexico \\ ${ }^{4}$ Centro de Estudios en Desarrollo Sustentable, Universidad Autónoma de Campeche, Avenida Héroe de Nacozari 480, C.P., 24079 San Francisco de \\ Campeche, Campeche, Mexico \\ ${ }^{5}$ Centro de Investigación en Enfermedades Infecciosas, Instituto Nacional de Enfermedades Respiratorias, Ismael Cosío Villegas, Calz. de Tlalpan 4502, \\ C. P., 14080 Ciudad de México, Mexico
}

\begin{abstract}
In the Americas, infectious viral diseases caused by viruses of the genus Mammarenavirus have been reported since the 1960s. Such diseases have commonly been associated with land use changes, which favor abundance of generalist rodent species. In the Americas - where the rates of land use change are among the highest worldwide - at least 1326 of all 2277 known rodent species have been reported. We conducted a literature review of studies between 1960 and 2020, to establish the current and historical knowledge about genotypes of mammarenaviruses and their rodent reservoirs in the Americas. Our overall goal was to show the importance of focusing research efforts on the American continent, since the conditions exist for future viral hemorrhagic fever (VHF) outbreaks caused by rodent-borne viruses, in turn, carried by widely distributed rodents. We found 47 species identified down to the species level, and one species identified only down to the genus level (Oryzomys sp.), reported in the Americas as reservoirs of mammarenaviruses, most these are ecological generalists. These species associate with 29 genotypes of Mammarenavirus, seven of which have been linked to VHFs in humans. We also highlight the need to monitor these species, in order to prevent viral disease outbreaks in the region.
\end{abstract}

Keywords: Arenaviridae, Mammarenavirus, Rodents, Ecology, LUC, Viral hemorrhagic fever, Gloria TapiaRamírez

\section{INTRODUCTION}

Nearly $60 \%$ of infectious diseases in humans are zoonotic (Taylor et al. 2001; Jones et al. 2008). Zoonoses are diseases

Published online: March 5, 2022

Correspondence to: Gloria Tapia-Ramírez, e-mail: tapiaramglo@gmail.com caused by pathogens, including bacteria, helminths, fungi and viruses, transmitted between animals and humans. Mammalian viruses are of special concern because some scholars have considered them potential agents for global pandemics (Jones et al. 2008; Geoghegan et al. 2016; Carrasco-Hernández et al. 2017). 
According to Carlson et al (2019), 10,000 out of 40,000 viruses borne by mammals have zoonotic potential. The mammalian orders bearing the higher proportion of zoonotic viruses are bats, primates and rodents (Carlson et al. 2019). Specifically, rodents are reservoirs of 78 zoonotic viruses, belonging to the order Bunyavirales, comprised of species belonging to the Hantaviridae and Arenaviridae families (Laenen et al. 2019; Radoshitzky et al. 2019).

The Arenaviridae family consists of four genera: Reptarenavirus, Hartmanivirus, (both of them borne by reptiles), Antennavirus, (borne by fishes) and, Mammarenavirus, borne by mammals, specifically rodents (Radoshitzky et al. 2019); although, there are reports of mammarenaviruses (Tacaribe virus) found in frugivorous bat Artibeus lituratus and in ixodid ticks (Downs et al. 1963; Sayler et al. 2014). The International Committee on Taxonomy of Viruses (ICTV, https://talk.ictvonline.org/taxono $\mathrm{my} /$ ) recognize forty genotypes of mammarenaviruses worldwide distributed, twenty-five are found in the Americas (Radoshitzky et al. 2019), seven of which are zoonotic agents of viral hemorrhagic fevers (VHFs) which could be severe or-sometimes-fatal for humans (CDC 2013).

Mammarenaviruses are bi-segmented RNA viruses with a genome of approximately $11,000 \mathrm{bp}$ contained in two single-stranded segments of RNA ( $\mathrm{S}$ and L): 3,400 bp in segment $\mathrm{S}$, and 7,200 bp in segment $\mathrm{L}$ (Bausch and Mills 2014). In the Americas, mammarenaviruses are carried by rodents of the Cricetidae family, which consists of 765 species in 142 genera and 5 subfamilies (Pardiñas et al. 2017). The existence of rodent species reservoirs of mammarenaviruses have been reported in two subfamilies: Neotominae and Sigmodontinae (Sarute and Ross 2017).

Rodent reservoirs of mammarenaviruses have been described as generalists (Mills 2005) or having peridomestic habits (Charrel and de Lamberrie 2010). Their condition as generalists is important for viral transmission because it increases chances of contact between reservoirs and new hosts, promoting events of interspecies viral spillover (Charrel and de Lamberrie 2010). Their role as reservoirs is favored by their morphological, physiological, and behavioral characteristics; for example, they have a high reproductive potential and reach high population densities, which contributes to viral transmission (Mills et al. 2007).

Worldwide, there is evidence on the role of rodents in the emergence of VHFs caused by mammarenaviruses. In the Americas, the first VHF was reported in Argentina in 1955 (Arribalzaga 1955) where the responsible rodent transmitting the virus to humans was Calomys musculinus.
Two other VHFs were later reported in South America, in Bolivia in 1959 (Mackenzie et al. 1964) and Venezuela in 1989 (Salas et al. 1991). Involved rodent species were Calomys callosus and Zygodontomys brevicauda, respectively. In Mexico, an epidemic outbreak in the state of Chiapas was reported in 1967 (Goldsmith and Shields 1971), with symptoms similar to those of South American VHFs. The rodent species involved was Peromyscus mexicanus. All aforementioned rodent species have the following characteristics in common: they are widely distributed, have a high reproductive rate and the ability to colonize a wide variety of habitats (Sarute and Ross 2017). The VHFs present in the Americas can reach human mortality rates between 5-30\% (PAHO 2021).

After the first outbreak in Argentina, some light was shed on the main drivers of VHFs emergence. Land use change (LUC) was considered the main driver in the emergence (Mills et al. 1992; Charrel and de Lamberrie 2010), because it promotes habitat destruction and changes in the original landscape structure; which modifies community rodent structure (Suzán et al. 2008; García-Peña et al. 2021), then, leading to greater numbers of generalists than specialists (Murphy and Romanuk 2014). Generalist species have the ability to rapidly colonize more than one habitat type and achieving high population densities, thereby favoring epidemic outbreaks (Mills 2005; Sarute and Ross 2017).

Since the Americas are under an accelerated LUC process and neglected diseases occur-caused by rodent borne mammarenaviruses-the objective of the present study was to review and compile information published in digital media regarding the role of native rodents as reservoirs of Mammarenavirus in the Americas. Our overall goal was to show the importance of focusing research efforts on the American continent, since the conditions exist for future outbreaks of VHFs caused by rodent borne viruses of wide distribution.

Therefore, we compiled information bringing together up-to-date data on genotypes of mammarenaviruses and their rodent reservoirs. Likewise, we show areas of confluence of more than one species of reservoir rodent on the continent. We have synthesized the available data on the relationship between land use change and the emergence of viral hemorrhagic fevers, and how this relationship is linked to the species' ecology and it is shaped by environmental factors. Finally, data on the phylogenetic and evolutionary relationships between mamarenaviruses and their rodent reservoirs were gathered. 


\section{Methods}

Using the search engines PubMed, Web of Science and Google Scholar we carried out a search of scientific articles published from 1960 to 2020 containing any combination of the following key words in the title or in the abstract: Arenavirus, Arenaviridae, Mammarenavirus, rodent reservoir, and the Americas. Year interval attending to the first outbreak reported in the Americas, in Argentina, near 1960. We also carried out a search of all arenaviruses recognized by the International Virus Taxonomy Committee (Radoshitzky et al. 2019).

Additionally, using the IUCN platform (IUCN 2020), we obtained geographic distributions for all reservoir species reported in the present document. We then identified overlapping areas of these distributions to visualize areas of convergence of more than one rodent reservoir species, where it could be necessary to put efforts for future studies because the potential contact between people and rodents. IUCN geographic distributions are accessible data, curated by experts in each species and are available for all the rodent species in this study. Previously have been used to show the overlapping promotes the co-circulation of viruses in the Americas (Luis et al. 2015; Milholland et al. 2018; Shipley et al. 2019).

Finally, we generated a series of maps containing all the above-mentioned information using QGIS 3.10.14 (QGIS Development Team 2020).

With the available data on LUC, along with the ecological and environmental factors, a conceptual framework was built explaining the role that LUC plays in the emergence of viral hemorrhagic fevers on the continent; as well as how some ecological and environmental factors interact to shape the response of rodents to these changes. Additionally, we try to explain the transmission routes of mammarenaviruses among the rodent populations and between species. The present study incorporates data from the southern United States to central Argentina.

\section{Results}

Our literature search generated 245 articles. In the first filter, all the reviews and chapter books were dismissed ( 28 items), because they were a compilation of previously published information and we were on the search of recent field publications. A second filter included reading the abstract of 217 articles, looking for the words of the search criteria described above. From 217 articles, 156 did not fulfill search criteria, that is, even though the arenaviridae was their main topic, there was no mention about rodent reservoirs or they were articles about Mammarenavirus of the Old World, with just a brief mention to the New World species; thus they were excluded. Finally, 61 articles were selected which had been published in 29 indexed journals.

\section{Rodents Reservoirs and Mammarenaviruses}

In the Americas, there are 47 species identified down to the species level, and one species identified only down to the genus level (Oryzomys sp.), of rodent reservoirs of mammarenaviruses. They are currently known to carry 27 of the 29 genotypes of Mammarenavirus. The remaining two genotypes have no rodent reservoir assigned yet (Table 1). Twenty-five genotypes are recognized by the International Committee on Taxonomy of Viruses (ICTV). There is a Mammarenavirus in the Americas not bearing by rodents but by bats, Tacaribe virus (TCV), included in Table 1 for the record.

Regarding rodent reservoirs, new mammarenaviruses have been isolated and described in 27 of 47 rodent reservoirs; 26 of which are from the Cricetidae family and one is from Muridae, which is a non-native rodent (Table 1). The remaining 20 rodents have been identified as having positive antibodies to some Mammarenavirus genotypes, but these viruses have not been isolated (Table 2). The 26 Cricetidae rodents reservoirs (where mammarenaviuses have been isolated) are widely distributed in the Americas, according to IUCN (IUCN 2020); eight of them are found in North America, and the remaining eighteen in Central and South America, from Panama to Chubut province, in Argentina [Insert Fig. 1a-d here]. Also, in smaller regions of the continent-like Mesoamerica (which includes the center of Mexico to Panama) - at least five other rodent reservoir species of mammarenaviruses are overlapping their distributions: Neotoma mexicana, Oryzomys couesi, Peromyscus melanophrys, Reithrodontomys sumichrasti, and Sigmodon toltecus, all of which are sympatric with P. mexicanus (Fig. 2).

Considering the genotypes of Mammarenavirus, the majority of them have been reported in South America than in North America, i.e. 19 versus. 9 [Insert Fig. 3 here], and nine of those found in South America have been reported in Brazil (Fernandes et al. 2019).

Contrary to prior considerations, a given rodent species may carry more than one virus species (Irwin et al. 


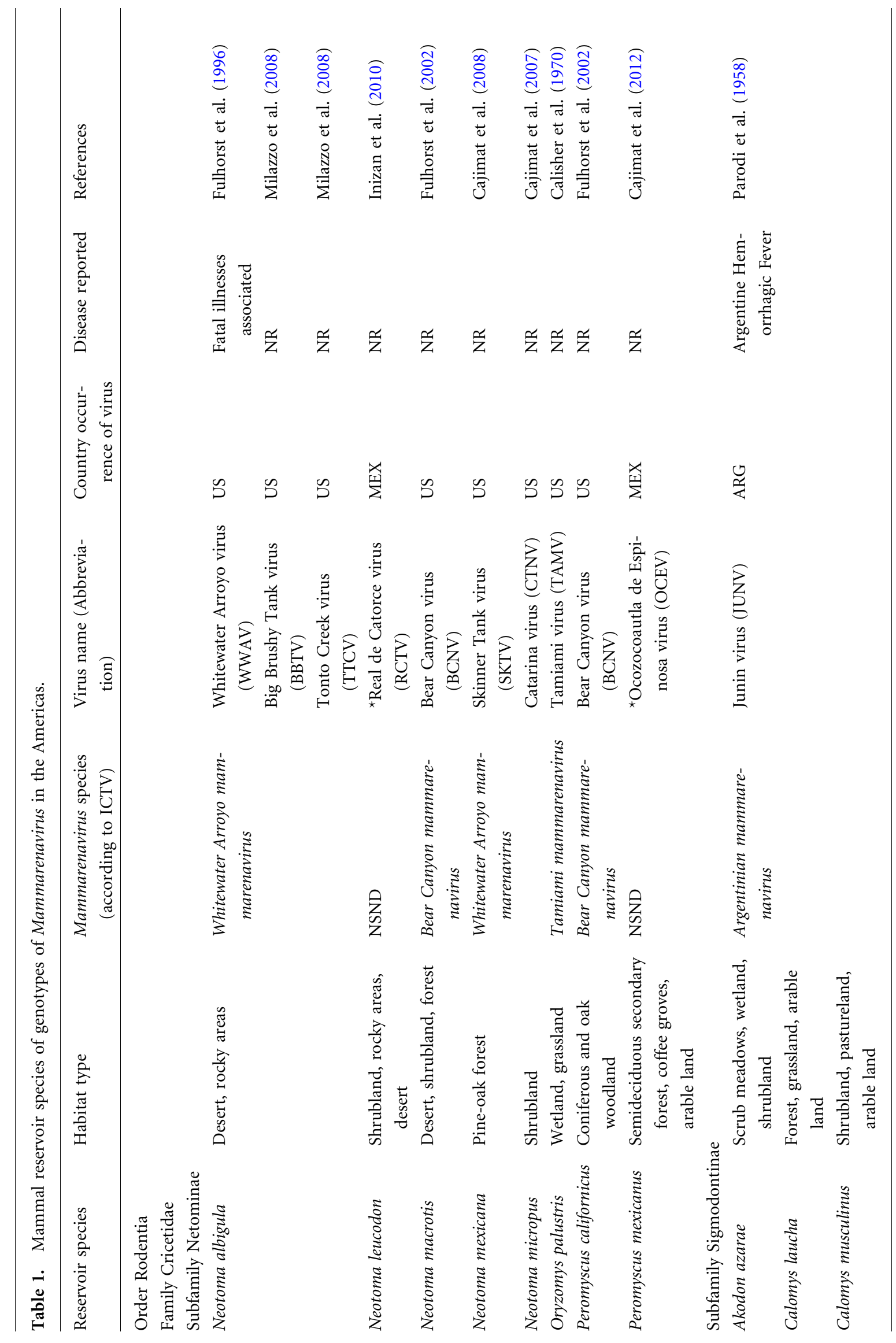




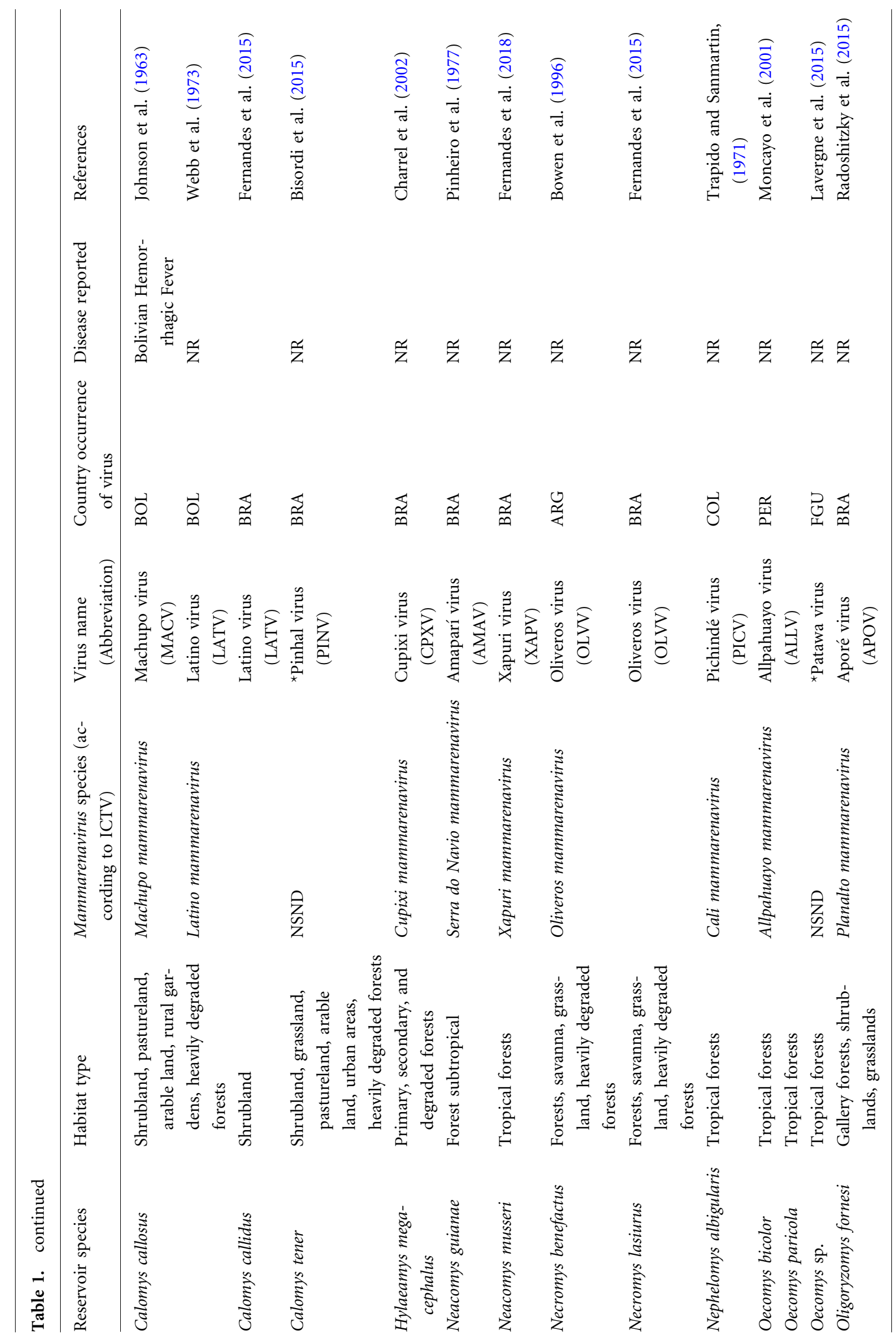




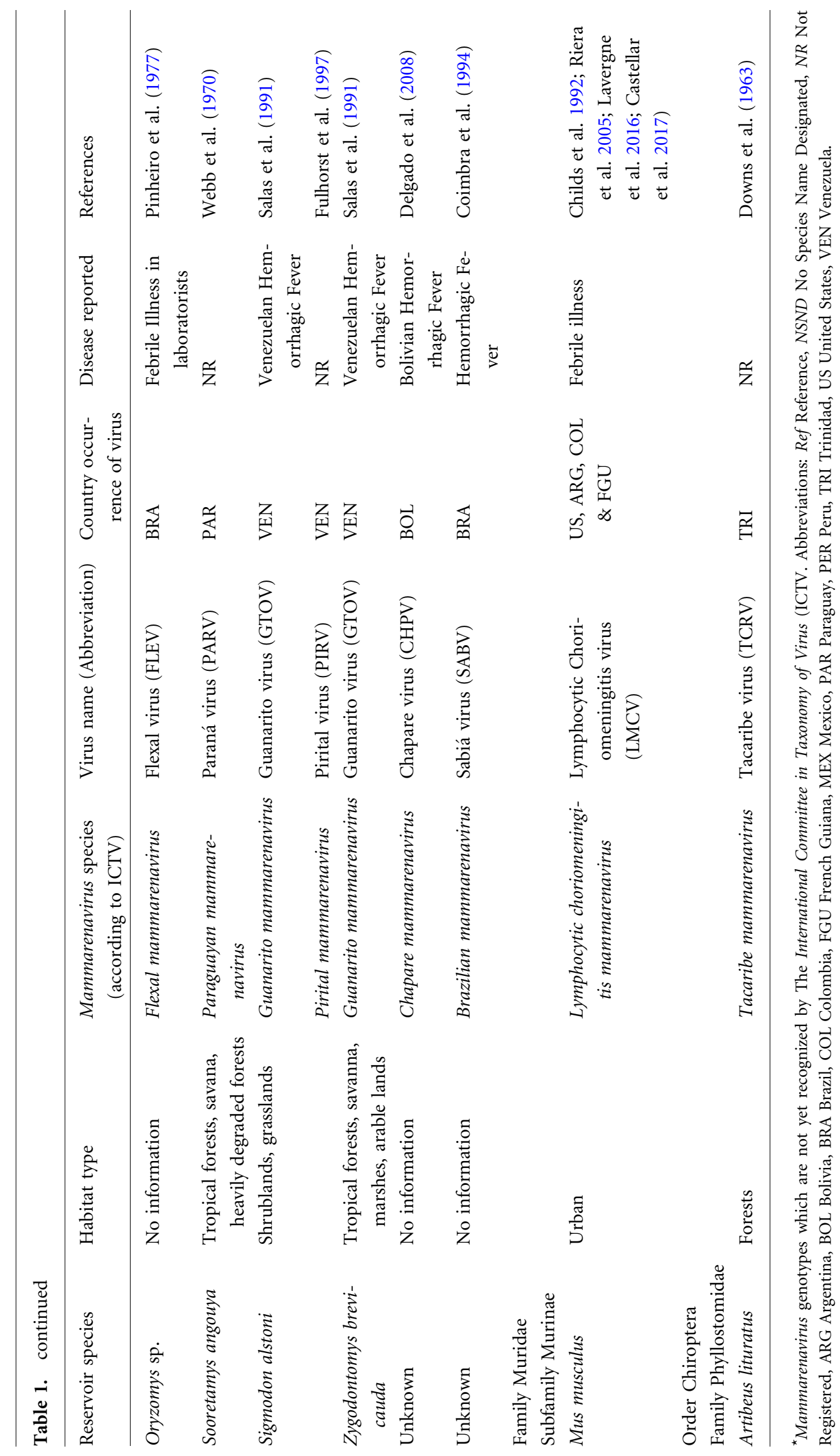


Table 2. Rodent species bearing antibodies to genotypes of Mammarenavirus in the Americas.

\begin{tabular}{|c|c|c|c|c|}
\hline Rodent species & Antibodies to & $\begin{array}{l}\text { Diseases } \\
\text { reported }\end{array}$ & $\begin{array}{l}\text { Distribution of rodent reservoir } \\
\text { species }\end{array}$ & Reference \\
\hline Baiomys taylori & WWAV \& AMAV & NR & US \& MEX & Milazzo et al. (2010) \\
\hline Megadontomys nelsoni & WWAV \& AMAV & NR & MEX & Milazzo et al. (2010) \\
\hline Neotoma fuscipes & $\begin{array}{l}\text { WWAV, AMAV, TAMV } \\
\text { \& PICV }\end{array}$ & NR & US \& MEX & Bennett et al. (2000) \\
\hline N. lepida & $\begin{array}{l}\text { WWAV, AMAV, TAMV } \\
\text { \& PICV }\end{array}$ & NR & US & Bennett et al. (2000) \\
\hline N. leucodon & WWAV \& AMAV & NR & US \& MEX & Milazzo et al. (2010) \\
\hline N. mexicana & WWAV \& AMAV & NR & US, MEX, HON, GUA \& SAL & Milazzo et al. (2010) \\
\hline N. micropus & WWAV \& AMAV & NR & US \& MEX & Milazzo et al. (2010) \\
\hline $\begin{array}{l}\text { Onychomys } \\
\text { leucogaster }\end{array}$ & WWAV \& AMAV & NR & CAN, US \& MEX & Milazzo et al. (2010) \\
\hline Oryzomys couesi & WWAV \& AMAV & NR & $\begin{array}{l}\text { US, MEX, BEL, COL, CRI, SAL, } \\
\text { GUA, HON, NIC \& PAN }\end{array}$ & Milazzo et al. (2010) \\
\hline O. palustris & WWAV \& AMAV & NR & US & Milazzo et al. (2010) \\
\hline Peromyscus attwateri & WWAV \& AMAV & NR & US & Milazzo et al. (2010) \\
\hline P. boylii & WWAV \& AMAV & NR & US \& MEX & Milazzo et al. (2010) \\
\hline P. californicus & $\begin{array}{l}\text { WWAV, AMAV, TAMV } \\
\text { \& PICV }\end{array}$ & NR & US \& MEX & Bennett et al. (2000) \\
\hline P. eremicus & $\begin{array}{l}\text { WWAV, AMAV, TAMV } \\
\text { \& PICV }\end{array}$ & NR & US \& MEX & Bennett et al. (2000) \\
\hline P. leucopus & WWAV \& AMAV & NR & CAN, US \& MEX & Milazzo et al. (2010) \\
\hline P. maniculatus & $\begin{array}{l}\text { WWAV, AMAV, TAMV } \\
\text { \& PICV }\end{array}$ & NR & CAN, US \& MEX & $\begin{array}{l}\text { (Bennett et al. 2000 } \\
\text { Milazzo et al. 2010) }\end{array}$ \\
\hline P. megalops & WWAV \& AMAV & NR & MEX & Milazzo et al. (2010) \\
\hline P. melanophrys & WWAV \& AMAV & NR & MEX & Milazzo et al. (2010) \\
\hline P. melanotis & WWAV \& AMAV & NR & US \& MEX & Milazzo et al. (2010) \\
\hline P. mexicanus & WWAV \& AMAV & NR & $\begin{array}{l}\text { MEX, GUA, HON, SAL, } \\
\text { CRI, NIC \& PAN }\end{array}$ & Milazzo et al. (2010) \\
\hline $\begin{array}{l}\text { Reithrodontomys } \\
\text { megalotis }\end{array}$ & $\begin{array}{l}\text { WWAV, AMAV, TAMV } \\
\text { \& PICV }\end{array}$ & NR & US \& MEX & Bennett et al. (2000) \\
\hline R. sumichrasti & WWAV \& AMAV & NR & $\begin{array}{l}\text { MEX, GUA, HON, SAL, } \\
\text { CRI, NIC \& PAN }\end{array}$ & Milazzo et al. (2010) \\
\hline Sigmodon hispidus & WWAV \& AMAV & NR & US & Milazzo et al. (2010) \\
\hline S. toltecus & WWAV \& AMAV & NR & MEX \& GUA & Milazzo et al. (2010) \\
\hline $\begin{array}{l}\text { Zygodontomys } \\
\text { brevicauda }\end{array}$ & $\mathrm{PICV}$ & NR & $\begin{array}{l}\text { BRA, COL, CRI, FGU, GUY, } \\
\text { PAN, SUR, TRT, VEN \& BOL }\end{array}$ & Mattar et al. (2011) \\
\hline
\end{tabular}

WWAV Whitewater Arroyo virus, AMAV Amaparí virus, TAMV Tamiami virus and PICV Pichindé virus; NR not reported; ARG Argentina, BEL Belize, BOL Bolivia, BRA Brazil, CAN Canada, COL Colombia, CRI Costa Rica, FGU French Guiana GUA Guatemala, GUY Guyana, HON Honduras, MEX Mexico, NIC Nicaragua, PAN Panama, SAL El Salvador, SUR Suriname, TRI Trinidad, US United States and VEN Venezuela. Published reports of antibodies detected through ELISA tests, according each author's criteria:

${ }^{*}$ Milazzo et al. (2010): A sample was considered positive if the AOD at 1:80 was $>0.200$, the AOD at 1:320 was $>0.200$, and the sum of the AOD for the series of fourfold dilutions (from 1:80 through 1:5120) was $>0.750$.

* Bennett et al. (2000): A serum was considered to be positive to a test antigen if the $\mathrm{OD}_{\text {adjusted }}$ at 1:80 and the $\mathrm{OD}_{\text {adjusted }}$ at 1:320 both were $\geq 0.200$, and the sum of the $\mathrm{OD}_{\text {adjusted }}$ for the series of fourfold dilutions (from 1:80 through 1:5,120) was $\geq 0.750$. 

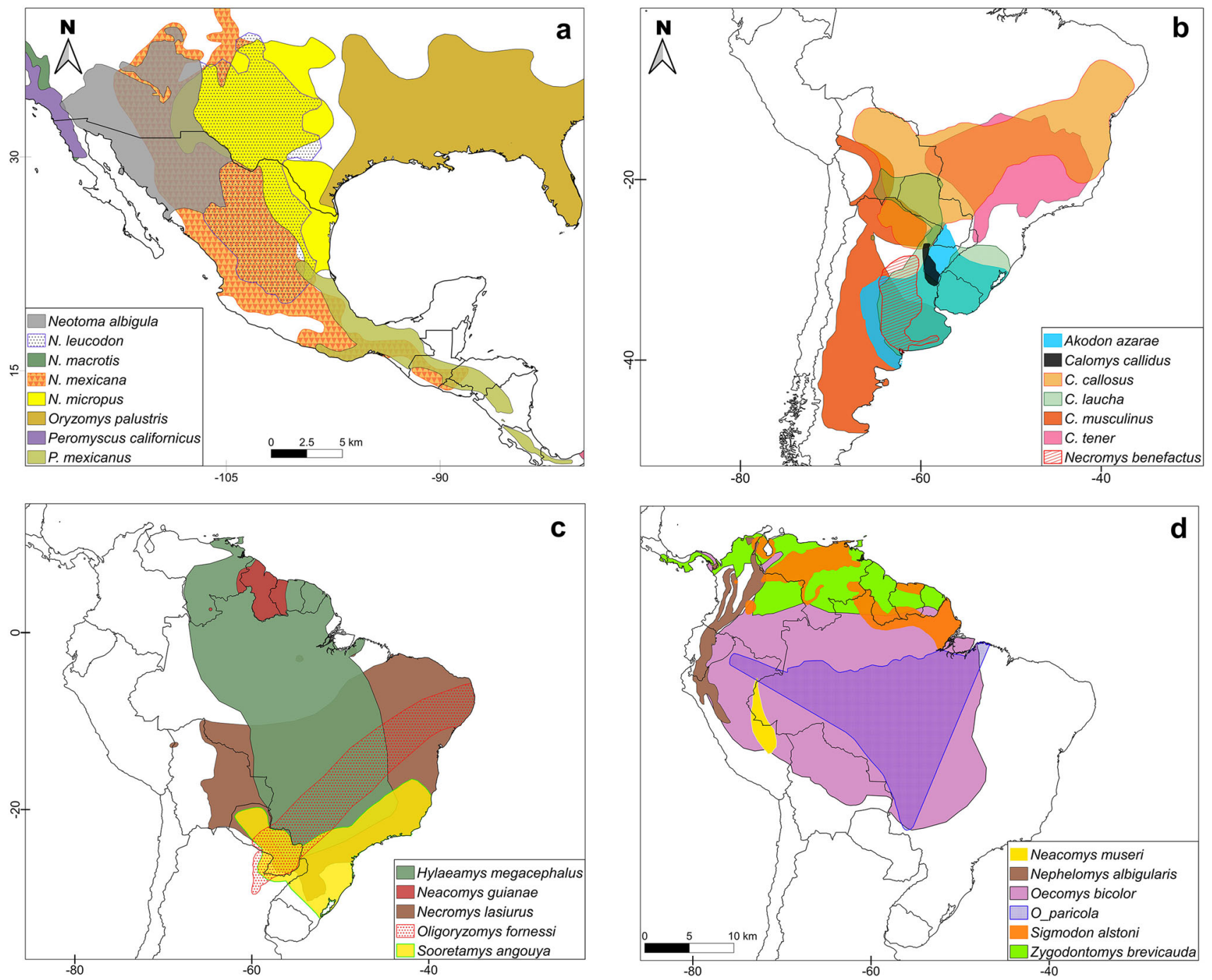

Figure 1. Geographic distributions of rodent reservoir species of mammarenaviruses in the Americas: a North America, b, c \& d South America Source of data distributions: IUCN (2020).

2012), as it occurs with the rodent Neotoma albigula, which is a reservoir for Whitewater Arroyo virus (WWAV), Big Brushy Tank virus (BBTV), and Tonto Creek virus (TTCV) in the USA (Table 1) (Fulhorst et al. 1996; Milazzo et al. 2008). The same occurs with Calomys callosus, which is a reservoir for Machupo virus (MACV) and Latino virus (LATV) in South America (Table 1) (Johnson et al. 1963; Webb et al. 1973). These findings have been markedly fostered by new molecular and serum detection techniques for mammarenaviruses contributing to the discovery and knowledge of these viruses and their reservoirs. In the Americas, from the earliest report, in 1960, until the 1990 's, 12 genotypes had been described (Fig. 4), however, this number almost tripled in the following two decades. In the past 10 years, four new mammarenaviruses have been described in Brazil (Fernandes et al. 2019) and two in Mexico (Inizan et al. 2010; Cajimat et al. 2012).

All the mammarenaviruses cited here are considered exclusive to the Americas, except for the Lymphocytic choriomeningitis mammarenavirus (LCMV) (Table 1), an Old World mammarenavirus, considered the prototype of the Arenaviridae family. It is worldwide distributed due to its rodent reservoir: Mus musculus, a non-native and also worldwide distributed rodent (Albariño et al. 2010). LCMV in the Americas has been reported in US, Colombia and Argentina (Riera et al. 2005; Foster et al. 2006; Lavergne et al. 2016; Castellar et al. 2017). It can infect other rodent species members of Muridae family in the Old World and can cause disease in humans, which could be asymptomatic or severe (Riera et al. 2005). 


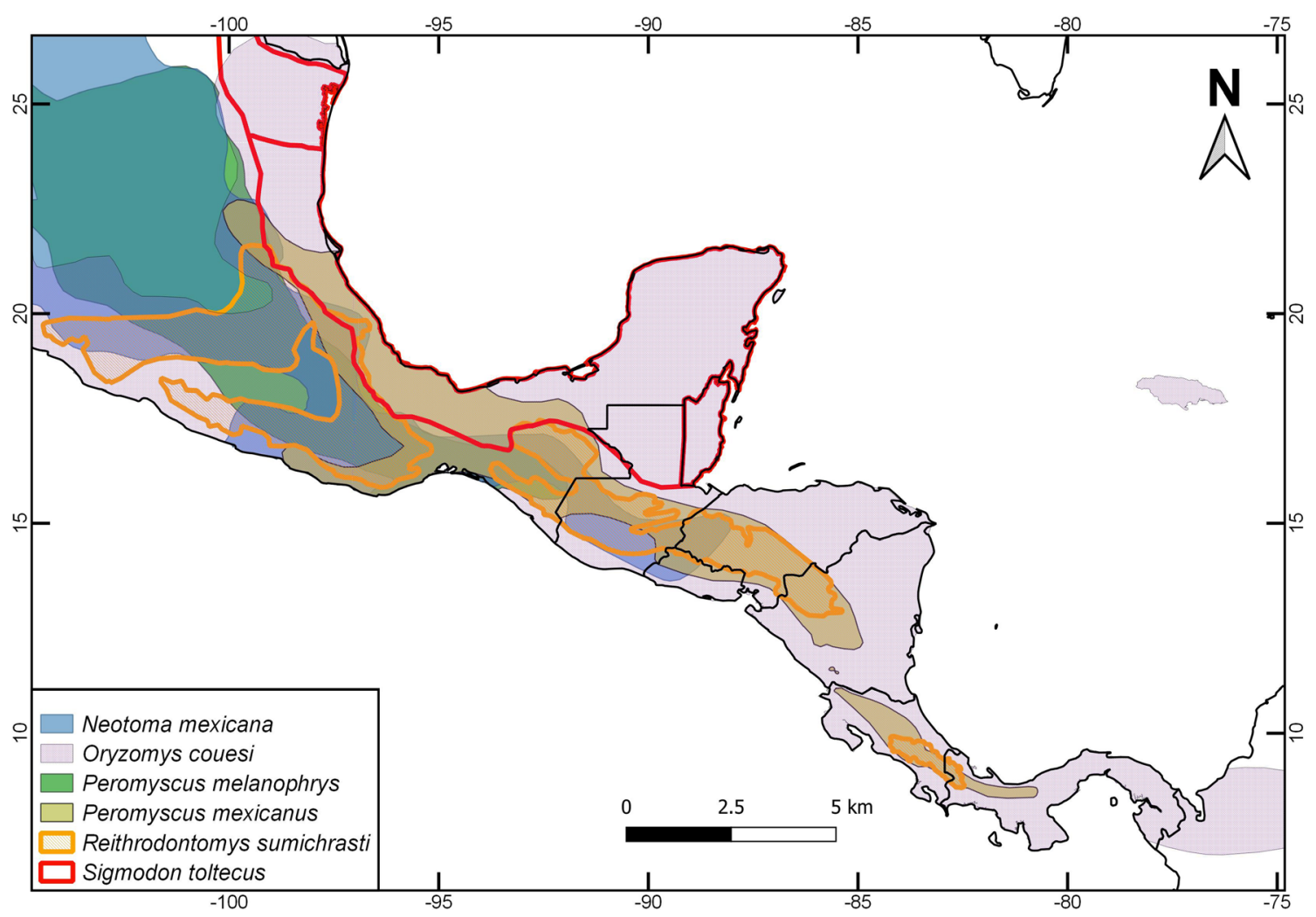

Figure 2. Geographic distributions of rodent reservoir species of mammarenaviruses in Mesoamerica (south of Mexico, Guatemala, Honduras, El Salvador, Nicaragua, Costa Rica and Panama).

Although, epidemic outbreaks and isolated deaths due to VHF from mammarenaviruses have been reported since the 1960s, their reservoir rodents have not been identified in all cases;-for example, those in the USA which have been attributed to WWAV (Byrd et al. 2000; Enserink 2000); those in Brazil, attributed to Flexal virus (FLEV) and Sabiá virus (SABV) (Barry et al. 1994; de Mello Malta et al. 2020); and those in Bolivia, attributed to Chaparé virus (CHAPV) (Escalera-Antezana et al. 2020).

\section{Land use Change, Reservoir Rodent Ecology, and Hemorrhagic Fever Emergence}

According to the information collected, mainly from the $70 \mathrm{~s}$ to the $90 \mathrm{~s}$, the factors influencing the emergence of VHFs in the continent are divided into anthropogenic, ecological and environmental, which are interconnected (Fig. 5).

\section{Anthropogenic Factors}

The main anthropogenic factor is land use change (LUC). The indiscriminate establishment of crops in the Americas shapes an agricultural landscape that changes the community structure and population dynamics of the original rodent species, which inhabited the area prior to the establishment of the agricultural landscape. Crops drive the loss of predators and specialist rodents and contribute to an increase in generalist species (Crespo 1966; de Villafañe et al. 1977; Kravetz et al. 1986; Carballal et al. 1988). The loss of some species is due-in part-to the fact that the structure of the rodent habitat is negatively affected as burrows are destroyed. Some individuals are killed, insects are eliminated and the availability of shelters is restricted (de Villafañe et al. 1977). On the other hand, it favors the disappearance of some predators (Kravetz et al. 1986), but also the arrival of others, e.g. dogs, cats or other larger rodents.

Once the agricultural landscape has been established, rodent populations will share that space following the local agricultural dynamics, generating a pulsation-like pattern of rodents' presence. That is, when a plot is in preparation for sowing, one species will occupy it, while, when it is planted there will be another species, and, yet another one, at harvest time (de Villafañe et al. 1977). A similar pattern 


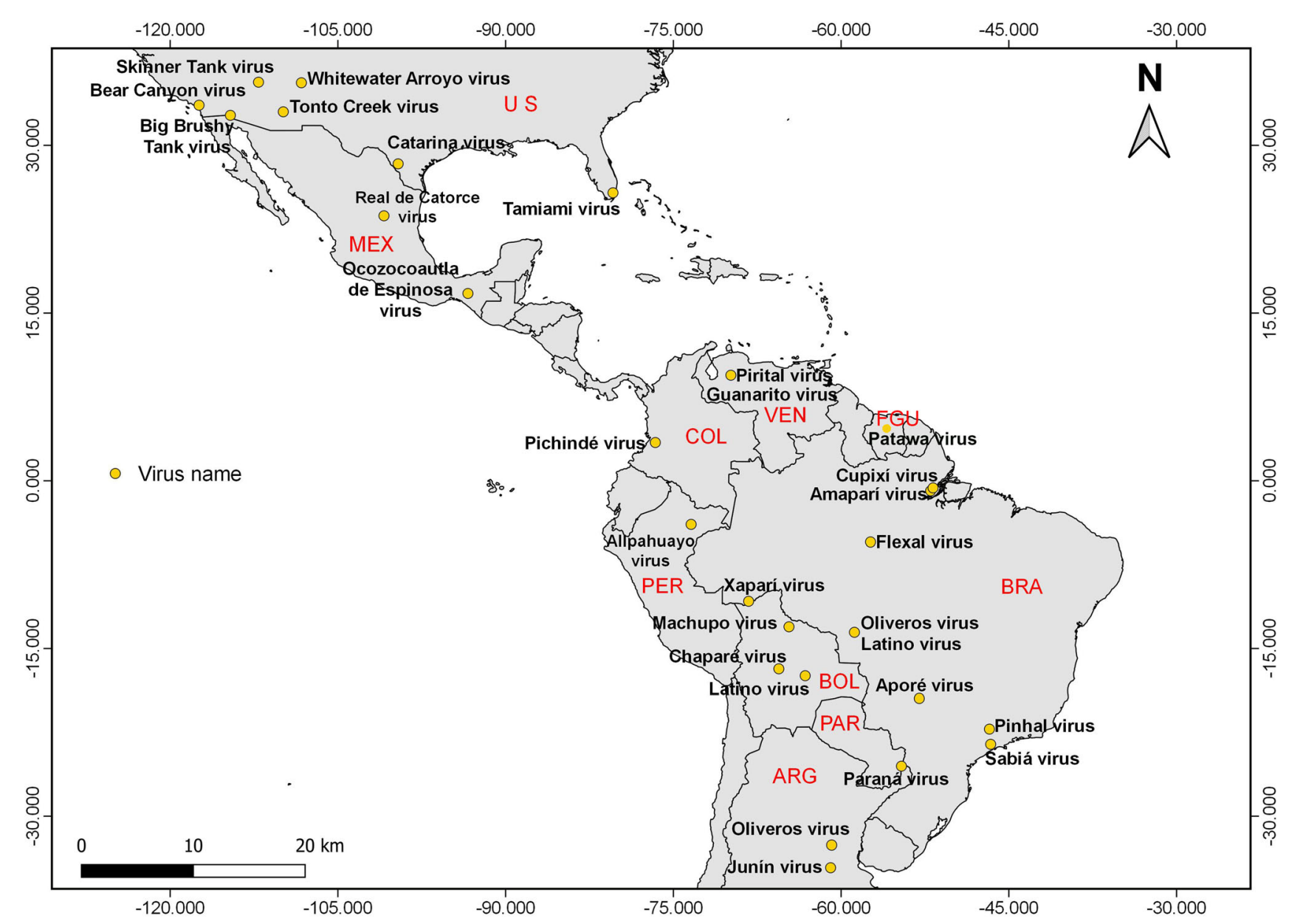

Figure 3. Geographic locations of Mammarenavirus genotypes in the Americas. Abbreviations: ARG Argentina, BOL Bolivia, BRA Brazil, COL Colombia, FGU French Guiana, MEX Mexico, PAR Paraguay, PER Peru, US United States, VEN Venezuela.

has been described for Sigmodon alstoni and Zygodontomys brevicauda in Venezuela, with species associated with the Venezuelan Hemorrhagic Fever (VHF) (Utrera and Duno 2007). Each rodent species utilizes the agricultural landscape during certain growth-stages of a crop according to its needs for food and protection. Because of this, certain species prove to be more abundant than others, potentially causing outbreaks of VHF (Ellis et al. 1997). In turn, VHF is related to seasonal population fluctuations and periods of higher rodent population density.

\section{Ecological Factors}

Rodent populations that remain in this agricultural landscape are distributed according to their habitat and food preferences. For example, in Pergamino, Argentina, the species involved in the transmission of the Junin virus (Akodon azarae, Calomys musculinus and C. laucha) occupy agricultural plots differentially (de Villañafe et al., 1977), according to their eating habits, (i.e. if rodent eat grains or grasses). Therefore, the populations of C. musculinus and $C$. laucha occupy the cornplots. While Akodon azarae, and Necromys obscurus occupy those of soybeans or alfalfa (de Villafañe et al. 1977; Kravetz et al. al. 1986; Mills et al. 1991). Additionally, these preferences are reinforced by interspecific competition between Akodon azarae and $C$. musculinus, which ends up displacing and confining the former to the edges of agricultural plots where the vegetation cover is more diverse and abundant (Carballal et al. 1988). This type of interaction has not been recorded between Calomys musculinus and C. laucha (de Villafañe et al. 1977), suggesting their coexistence in agricultural plots. This should favor their role in the transmission of the Junin virus to rural workers (Mills et al. 1991). The occupation of the species-in these habitats - is a direct function of the dispersal ability and the capacity of the rodent species to 


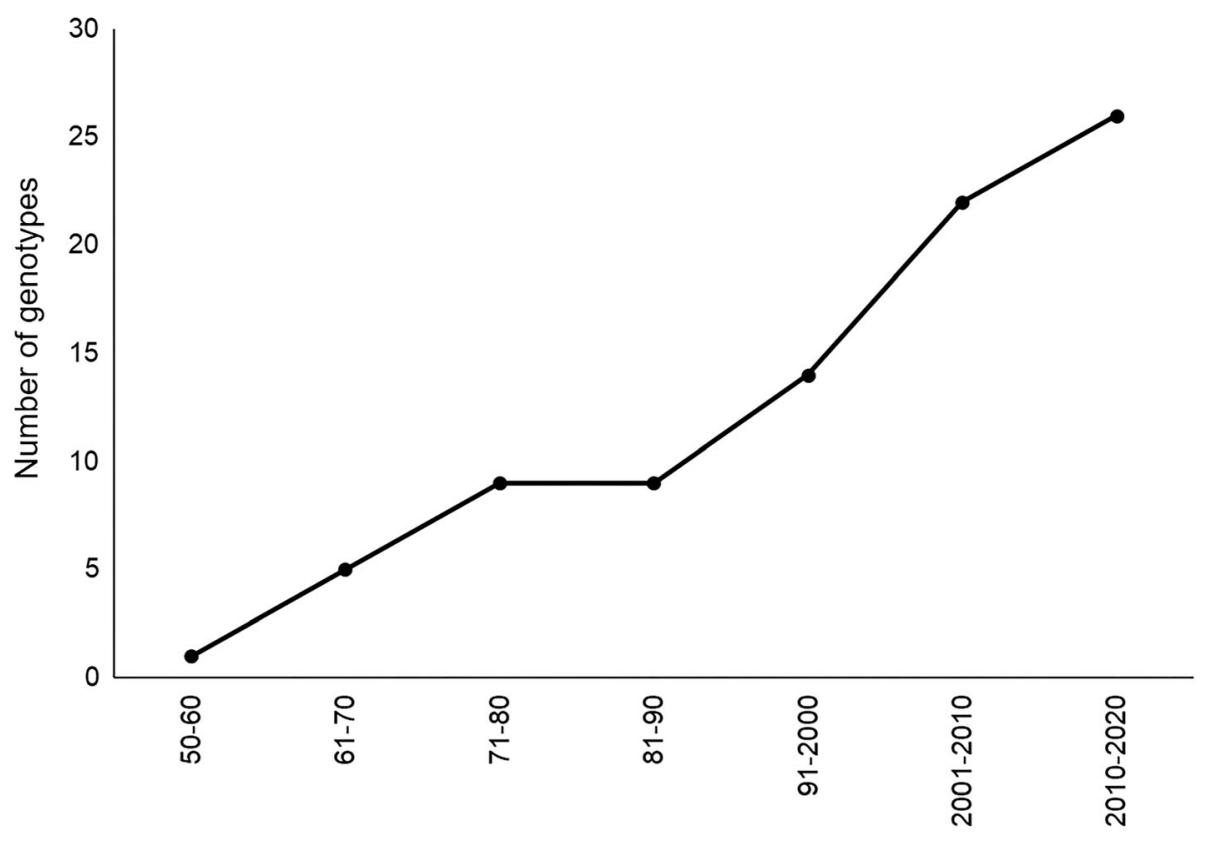

Year of discover

Figure 4. Cumulative number of genotypes registered in the Americas since 1960.

reproduce, since they are $\mathrm{R}$ strategists (i.e., having numerous litters in short periods of time) (de Villafañe et al. 1977).

A relationship has been suggested between density of reservoir rodents (in those cases Calomys musculinus) and incidence of disease (Crespo 1966; Mills et al. 1992). For example, Mills et al. (1991), Crespo (1966) and de Villafañe et al. (1977) reported that the population density of Calomys musculinus is higher from spring to early southern autumn (between September and March), while Akodon azarae is not very abundant at that time and increases its population density between March and April, after harvest.

\section{Environmental Factors}

A bottom-up effect has been suggested causing increased population sizes of reservoir rodents due to changes in precipitation; thus, leading to increased food availability and, in turn, numerous cases of VHF (Mills et al. 1992). Changes in temperature have also been associated to resource availability. For example, Mills et al. (1992) associated low temperatures to low resource availability, because of decreased rain. In turn, sites with temperate climates, less temperature variations and more rain accommodate a larger diversity of rodents, as well higher abundance of
Calomys musculinus (Mills and Childs 1998; Chiappero et al. 2018).

Other factors influencing spatial patterns and rates of dispersion of VHF in a given territory include the genetics of the rodent populations involved, geographic boundaries, local extinctions of rodents or viruses, environmental variables, and intrinsic properties of a reservoir community which allow it to support long-term maintenance of a virus (Polop et al. 2008). According to Polop et al. (2008), the prevalence of Junin virus in Argentinian rodents could be greater in the area of endemism than in sites far from it, under certain conditions. In the endemic area, reservoir rodent populations are large and genetic flow occurs among them. These areas may favor the presence of generalist rodents given the abundance of food (Polop et al. 2007). However, outside the endemic area reservoir rodent populations are separated from each other, and little or no genetic flow occurs among them; thus, these areas act as islands (Delgado et al. 2008). Environmental conditions and local vegetation determine which rodent populations makes use of these "islands", as well as when and where. While viruses may infect a local population, if such population does not become abundant after a certain time period, the infectious cycle may be stopped. Nevertheless, this hypothesis requires further study. 


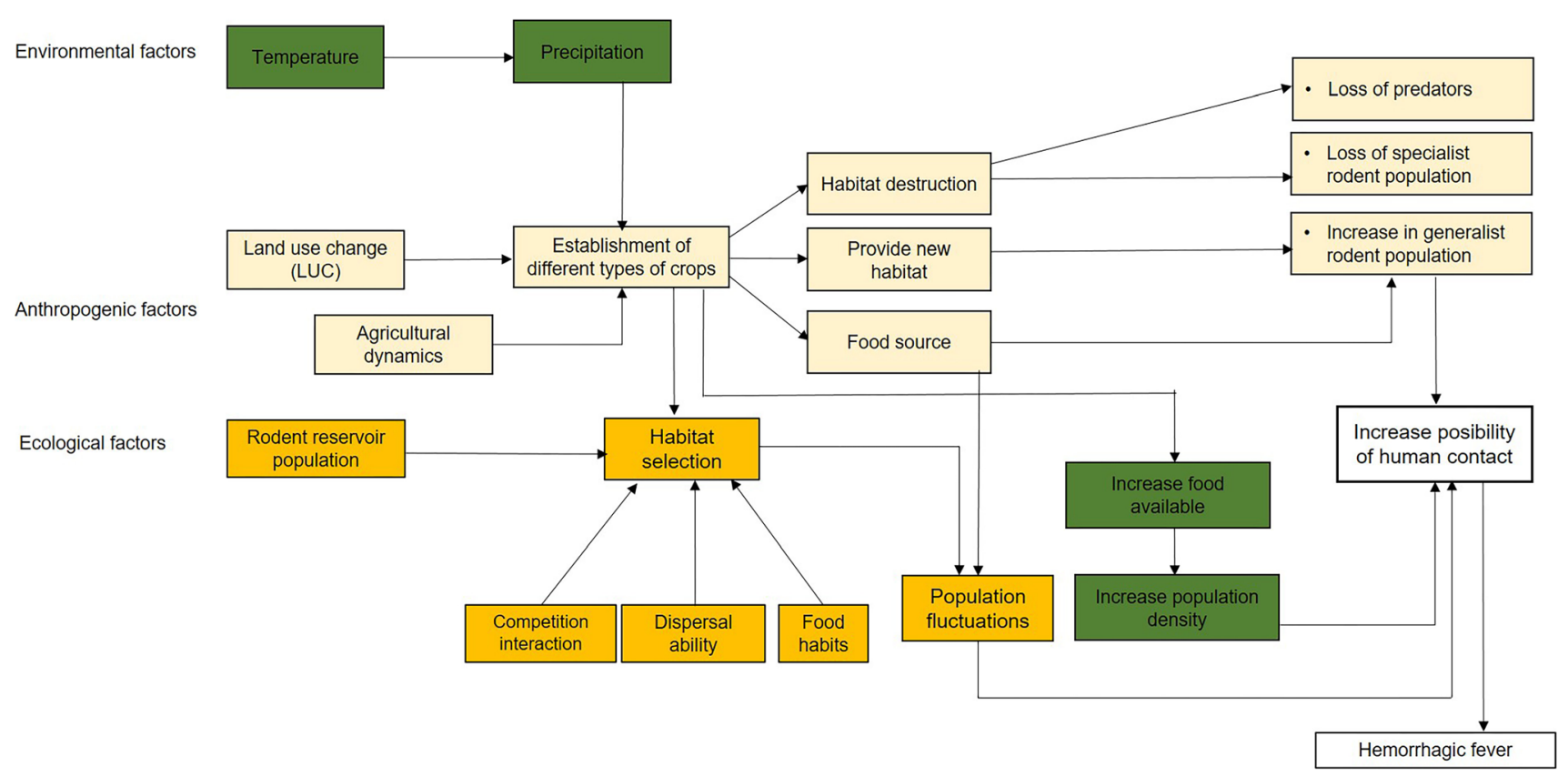

Figure 5. Conceptual model of ecology of rodent reservoirs of mammarenaviruses and their relationship with conservation of virus and transmission of it.

\section{Transmission of mammarenaviruses}

The way in which mammarenaviruses keep circulating in the population of reservoir rodents is key in determining the preservation of the virus, and its transmission to other members of the population, to other populations and to humans. In rodent populations there are two routes of transmission. The first of them-the horizontal routeoccurs through the aerosolized particles secreted through feces, urine, saliva or sexual route (Sabattini et al. 1977). It has been suggested that the infection also occurs by rodentrodent contact, specifically among adult male individuals exhibiting aggressive behaviors; thus, causing wounds through which the pathogen is transmitted (Mills et al. 1992). This can increase prevalence of infection in dense populations, since, the prevalence of infection is densitydependent and this, in turn, is associated to seasonal changes. The other route is vertical, which occurs from parent to progeny. It is known that-at least in the case of the Junin virus-the offspring becomes infected after being born, so it is believed that infection occurs via breast milk (Pinheiro et al. 1977; Sabattini et al. 1977). According to Pinheiro et al. (1977) and Vitullo and Merani (1988), the vertical path does not play an important role in the transmission of Mammarenavirus under normal circumstances; however, it could be important for the maintenance of the virus in the population in the long term.
Two main transmission routes between rodents and humans have been described for mammarenaviruses: i) through aerosolized particles secreted by rodents in feces, urine, or saliva (Charrel et al. 2001), and ii) through direct contact with a rodent's body fluids, such as saliva, mucous, or blood through bites from carriers or upon consuming a rodent (Ter Meulen et al. 1996); as it is customary, for example, in some parts of Mexico (Barragán et al. 2007).

\section{Phylogenetic Studies of Mammarenaviruses and Rodents}

The Arenaviridae family is divided into two groups-or "complexes"-based on their antigenic properties: i) the Lassa-Lymphocytic Choriomeningitis complex, present in the Old World, and ii) the Tacaribe complex, in the New World (Queen et al. 2015). These complexes are also differentiated based on the family of rodents carrying them: Muridae in the Old World and Cricetidae in the New World (Arata and Gratz 1975).

The Tacaribe complex is divided into three lineages: A, $\mathrm{B}$, and $\mathrm{C}$. Lineage $\mathrm{A}$ is the oldest, containing the viruses FLEV, PARV, PICV, and TAMV. Lineage B contains AMAV, GUAV, JUNV, MACV, SAB, and TCRV and includes all pathogenic viruses except Tacaribe (Bowen et al. 1996). Lineage C contains LATV and OLVV. 
Regarding the phylogeny of these viruses, until 2018, researchers have suggested that, since the time of origin of rodents, these viruses evolved in parallel with their reservoirs (Zapata and Salvato 2013; Shi et al. 2018). The first contact between a viral prototype of the Arenaviridae family and a rodent likely occurred in Asia 23 million years ago with rodents from the Muridae family (González et al. 2007). They expanded from Asia to Africa and Europe and, 20 million years ago, they crossed the Bering Strait to North America; where they diverged into the ancestors of the Neotominae and Sigmodontinae subfamilies. The latter probably already carried the ancestors of the mammarenaviruses of the Americas (González et al. 2007; Zapata and Salvato 2013). Researchers previously thought that each viral species was associated with a single rodent species and therefore the rodent's distribution determined that of the virus (Charrel et al. 2001).

However, based on the complete phylogeny of the Cricetidae rodent family and the currently-known mammarenaviruses in the Americas, it has been suggested that the supposed parallel relationship is rather a co-divergence (Irwin et al. 2012). Mammarenaviruses of the Americas are randomly distributed within the phylogenetic tree of Cricetidae rodents, and therefore a randomly distributed group of pathogenic viruses could infect a variety of rodent species and even other orders of mammals (host-switching) (Irwin et al. 2012). Over time, some Mammarenavirus genotypes have been found in more than one rodent species; for example, BCNV infects both Neotoma microtis and Peromyscus californicus (Irwin et al. 2012). Similarly, LATV, originally found in Calomys callosus in Bolivia, was recently detected in C. callidus in Brazil (Fernandes et al. 2018).

Still, some authors suggest that the probability of a virus successfully colonizing a new reservoir species is greater if the new species is a close relative of the primary reservoir (Cuthill and Charleston 2013). Therefore, in the evolutionary history of vertebrate RNA viruses, spillovers in reservoirs may have been more common than co-divergence; particularly, among reservoirs sharing a given environment (Shi et al. 2018). Thus, the evolution of arenaviruses appears to be the product of a relationship between co-divergence of a virus and its reservoir, on the one hand, and frequent transmission among sympatric rodent species on the other (Geoghegan et al. 2017).

\section{Discussion}

This review reports, to date, the existence of 47 species of reservoir rodents, bearing 26 genotypes of Mammarenavirus; seven of which can cause mild to severe hemorrhagic fevers (VHF) in humans. Two of those seven genotypes have not yet been associated with any known rodent. VHFs due to mammarenaviruses have occurred in Argentina, Bolivia, Venezuela and some isolated cases are known in Brazil and the USA. Twenty-out of the 47 species of rodents-have only tested antibody positive to mammarenaviruses, i.e. no novel mammarenaviruses have been isolated from these rodents. In this regard, the potential role of cross-reactivity-a relatively common phenomenon in heterologous viruses-must be recognized. In fact, Brehm et al. (2002) recognized this reactivity and suggested that it improves protection against subsequent viral stimuli, also, improving the pool of memory of T cells; which is why it is common to find reactivity to more than one type of virus in a single species of rodent. Moreover, rodent species where antibodies have been detected are also located in North America and they are mostly generalists, sympatric and with a wide distribution throughout the American Continent.

Regarding the factors related to the emergence of viral hemorrhagic fever (VHF), land use change has been mentioned repeatedly. In particular, the establishment of agricultural plots, which modifies the rodent community structure and abundance of reservoir species (de Villafañe et al. 1977, 1988; Villafañe and Bonaventura 1987; Mills et al. 1992). There are also mentions to an association with temperature and precipitation (Mills et al. 1992; Polop et al. 2008). In this regard, recent studies confirmed the hypothesis that human alterations in ecosystems create favorable habitats for reservoirs of zoonotic pathogens (Mendoza et al. 2020). In the American continent, this topic has been constantly investigated in cases of VHF emergence by Orthohantavirus (Suzán et al. 2008; Andreo et al. 2014; Rubio et al. 2014; Carver et al. 2015; Prist et al. 2021). The conclusions of these authors are important because some of the rodent species are reservoirs of both Orthohantavirus and Mammarenavirus; and the set of factors promoting transmission of viruses to humans are the same (Prist et al. 2021 and this work).

On the other hand, a concomitant factor that should be explored is climate change. Which, in turn, leads to increases and changes in meteorological patterns (Gubler 
et al., 2001; Greer et al., 2008; Maroli et al., 2018; Tian and Stenseth, 2019). Climate and meteorological changes have often been studied in the Americas during outbreaks of Orthohantavirus-associated pulmonary syndrome (HPS), which has been associated with increases in temperature (Prist et al. 2016), precipitation (Yates et al. 2002), and humidity (EcoHealth Alliance 2019; Everard et al. 2020).

This work has found that-in the continent-certain geographic regions can present between six (Mesoamerica) and up to nine (Brazil, Bolivia, Peru and Panama) species of reservoirs. These areas are consistent with the regions, designated by Han et al. (2015), as areas of high diversity and, on the other hand, areas with high rates of zoonotic risk (García-Peña et al. 2021). These authors project risk scenarios based on anthropogenic factors such as land use, but they also consider the possible risk of exposure of the human population. For this reason, the authors consider it necessary to carry out research in these areas considered as areas prone to zoonotic risk scenarios.

\section{CONCLUSION}

In the past 60 years, 28 genotypes of Mammarenavirus have been described; seven of which are pathogenic to humans. In the past 60 years in the Americas, the number of identified rodent reservoir species of mammarenaviruses has increased from 10 to 47 -including specialists and generalists-all of which are common generalist species in peridomestic environments and agricultural areas. The data show that there could be more than one risk spot for the emergency of a new hemorrhagic fever.

\section{ACKNOWLEDGEMENTS}

GTR was supported by a CONACYT PhD scholarship. We thank two anonymous reviewers for their comments to improve our manuscript.

\section{Declarations}

CONFLICT OF INTEREST The authors declare that they have no conflict of interest.

\section{Open Access}

This article is licensed under a Creative Commons Attribution 4.0 International License, which permits use, sharing, adaptation, distribution and reproduction in any medium or format, as long as you give appropriate credit to the original author(s) and the source, provide a link to the Creative Commons licence, and indicate if changes were made. The images or other third party material in this article are included in the article's Creative Commons licence, unless indicated otherwise in a credit line to the material. If material is not included in the article's Creative Commons licence and your intended use is not permitted by statutory regulation or exceeds the permitted use, you will need to obtain permission directly from the copyright holder. To view a copy of this licence, visit http://creativec ommons.org/licenses/by/4.0/.

\section{REFERENCES}

Albariño CG, Palacios G, Khristova ML, et al. (2010) High diversity and ancient common ancestry of Lymphocytic Choriomeningitis virus. Emerging Infectious Diseases Journal 16:1093-1100. https://doi.org/10.3201/eid1607.091902

Andreo V, Neteler M, Rocchini D, et al. (2014) Estimating hantavirus risk in Southern Argentina: A GIS-based approach combining human cases and host distribution. Viruses 6:201222. https://doi.org/10.3390/v6010201

Arata AA, Gratz NG (1975) The structure of rodent faunas associated with arenaviral infections. Buletin of World Health Organization 52:621-627

Arribalzaga RA (1955) Una nueva enfermedad epidémica a germen desconocido: Hipertermia nefrotóxica, leucopénica y enantemática. Dia Médico 37:1204-1210

Barragán F, Retana OG, Naranjo EJ (2007) The rodent trade of tzeltal indians of Oxchuc, Chiapas, Mexico. Human Ecology 35:769-773. https://doi.org/10.1007/s10745-007-9116-7

Barry M, Bia F, Cullen M (1994) Dembry L (1994) Arenavirus Infection-Connecticut. Journal of American Medical Association 272(13):998-999

Bausch DG, Mills JN (2014) Arenaviruses: Lassa Fever, Lujo Hemorrhagic Fever, Lymphocytic Choriomeningitis, and the South American Hemorrhagic Fevers. In: Viral Infections of Humans, Kaslow RA, Stanberry LR, LeDuc JW (editors), New York, US: Springer, pp 147-191

Bennett SG, Milazzo ML, Webb J, Fulhorst CF (2000) Arenavirus antibody in rodents indigenous to coastal southern California. American Journal of Tropical Medicine and Hygiene 62:626-630. https://doi.org/10.4269/ajtmh.2000.62.626

Bisordi I, Levis S, Maeda AY, Suzuki A, Nagasse-Sugahara TK, De Souza RP, Pereira LE, García JB, Cerroni MP, e Silva FDA, dos Santos CLS, da Fonseca BAL (2015) Pinhal virus, a new Arenavirus isolated from Calomys tener in Brazil. Vector-Borne and Zoonotic Disease 15:694-700 
Bowen MD, Clarence JP, Mills JN, Nichol ST (1996) Oliveros virus: a novel Arenavirus from Argentina. Virology 217:362-366

Brehm MA, Pinto AK, Daniels KA, et al. (2002) T cell immunodominance and maintenance of memory regulated by unexpectedly cross-reactive pathogens. Nature Immunology 3:627634. https://doi.org/10.1038/ni806

Byrd RG, Cone LA, Commess BC, Williams-Herman D, Rowland JM, Lee B, Fitzgibbons MW, Glaser CA, Jay MT, Fritz C, Ascher MS, Cheung M, Kramer VL, Reilly K, Vugia DJ, Fulhorst CF, Milazzo ML, Charrel RN (2000) Fatal illnesses associated with a New World Arenavirus, California, 1999-2000. Journal of American Medical Association 284:1237-1238. https://doi.org/ 10.1001/jama.284.10.1237

Cajimat MNB, Milazzo ML, Bradley RD, Fulhorst CF (2007) Catarina virus, an arenaviral species principally associated with Neotoma micropus (Southern plains woodrat) in Texas. American Journal of Tropical Medicine and Hygiene 77:732-736. https://doi.org/10.4269/ajtmh.2007.77.732

Cajimat MNB, Milazzo ML, Borchert JN, Abbott KD, Bradley RD, Fulhorst CF (2008) Diversity among Tacaribe serocomplex viruses (Family Arenaviridae) naturally associated with the Mexican woodrat (Neotoma mexicana). Virus Research 133:211217

Cajimat MNB, Milazzo ML, Bradley RD, Fulhorst CF (2012) Ocozocoautla de Espinosa virus and Hemorrhagic Fever, Mexico. Emerging Infectious Diseases Journal 18:401-405

Calisher CH, Tzianabo T, Lord RD, Coleman PH (1970) Tamiami virus, a new member of Tacaribe group. American Journal of Tropical Medicine and Hygiene 19:520-526

Carballal G, Videla CM, Merani MS (1988) Epidemiology of Argentine Hemorrhagic Fever. European Journal of Epidemiology $4: 259-274$

Carlson CJ, Zipfel CM, Garnier R, Bansal S (2019) Global estimates of mammalian viral diversity accounting for host sharing. Nature Ecology \& Evolution 3:1070-1075. https://doi.org/ 10.1038/s41559-019-0910-6

Carrasco-Hernandez R, Jácome R, López Vidal Y, Ponce de León S (2017) Are RNA viruses candidate agents for the next global pandemic? A Review Institute for Laboratory Animal Research Journal 58(3):343-358. https://doi.org/10.1093/ilar/ilx026

Carver S, Mills JN, Parmenter CA, et al. (2015) Toward a mechanistic understanding of environmentally forced zoonotic disease emergence: Sin Nombre Hantavirus. Bioscience 65:651-666. https://doi.org/10.1093/biosci/biv047

Castellar A, Guevara M, Rodas JD, Lodoño AF, Arroyave E, Díaz FJ, Levis S, Blanco PJ (2017) Primera evidencia de infección por el virus de la Coriomeningitis Linfocítica (Arenavirus) en roedores Mus musculus capturados en la zona urbana del municipio de Sincelejo, Sucre. Colombia. Biomédica 37:75-85

CDC (2013) Old World/New World Arenaviruses. Viral Hemorrhagic Fevers (VHFs). Available:https://www.cdc.gov/vhf/virusfamilies/arenaviruses.html [accessed July 2, 2020]

Charrel RN, De Lamballerie X, Fulhorst CF (2001) The Whitewater Arroyo virus: Natural evidence for genetic recombination among Tacaribe serocomplex viruses (family Arenaviridae). Virology 283:161-166. https://doi.org/10.1006/viro.2001.0874

Charrel RN, Feldmann H, Fulhorst CF, Khelifa R, de Chesse R, de Lamballerie X (2002) Phylogeny of New World arenaviruses based on the complete coding sequences of the small genomic segment identified an evolutionary lineage produced by intrasegmental recombination. Biochemical and Biophysical Research Communications 296:1118-1124
Charrel RN, de Lamberrie X (2010) Zoonotic aspects of Arenavirus infections. Veterinary Microbiology 140:213-220

Chiappero MB, Piacenza MF, Provensal MC, Calderón GE, Gardenal CN, Polop JJ (2018) Effective population size differences in Calomys musculinus, the host of Junín virus: their relationship with the epidemiological history of Argentine Hemorrhagic Fever. American Journal of Tropical Medicine and Hygiene 99:445-450. https://doi.org/10.4269/ajtmh.17-0838

Childs JE, Glass GE, Korch GW, Ksiazek TG, Leduc JW (1992) Lymphocytic Choriomeningitis virus infection and house mouse (Mus musculus) distribution in urban Baltimore. American Journal of Tropical Medicine and Hygiene 47:27-34

Coimbra TLM, Nassa ES, Burattini MN, Madia de Souza LT, Ferreira IB, Rocco IM, Travassos da Rosa APA, Vasconcelos PFC, Pinheiro FP, LeDuc JW, Rico-Hesse R, Gonzalez JP, Jahrling P, Tesh RB (1994) New arenaviruses isolated in Brazil. Lancet 343:391-392

Crespo JA (1966) Ecología de una comunidad de roedores silvestres en el Partido de Rojas, Provincia de Buenos Aires. Buenos Aires: Comisión Nacional Coordinadora para Estudio y Lucha contra la Fiebre Hemorrágica Argentina. Secretaría de Estado de Salud Pública

Cuthill JH, Charleston MA (2013) A simple model explains the dynamics of preferential host switching among mammal rna viruses. Evolution 67:980-990. https://doi.org/10.1111/ evo. 12064

de Mello Malta F, Amgarten D, de Seixas Santos Nastri AC, Ho YL, Casadio LVB, Basqueira M, Selegatto G, Cervato MC, Duarte-Neto AN, Higashino HR, Medeiros FAF, Gendler JLPL, Levin AS, Pinho JRR (2020) Sabiá virus-like Mammarenavirus in patient with fatal hemorrhagic fever, Brazil, 2020. Emerging Infectious Diseases Journal 26:1332-1334. https://doi.org/ 10.3201/EID2606.200099

de Villafañe G, Bonaventura SM, Bellocq MI, Percich RE (1988) Habitat selection, social structure, density and predation in populations of Cricetine rodents in the Pampa region of $\mathrm{Ar}$ gentina and the effects of agricultural practices on them. Mammalia 52:339-360. https://doi.org/10.1515/mamm-19880305

de Villafañe G, Bonaventura SM (1987) Ecological studies in crop fields of the endemic area of Argentine Hemorrhagic fever. Calomys musculinus movements in relation to habitat and abundance. Mammalia 51:233-248

de Villafañe G, Kravetz FO, Donald O, Percich R, Knecher L, Torres MP, Fernández N (1977) Dinámica de las comunidades de roedores en agroecosistemas Pampásicos. Revista Medicina 37:128-140

Delgado S, Erickson BR, Agudo R, Blair PJ, Vallejo E, Albariño CG, Vargas J, Comer JA, Rollin PE, Ksiazek TG, Olson JG, Nichol ST (2008) Chapare virus, a newly discovered Arenavirus isolated from a fatal hemorrhagic fever case in Bolivia. PLoS Pathogens 4:1-6. https://doi.org/10.1371/journal.ppat.1000047

Downs WG, Anderson CR, Spence L, Aitken THG, Greenhall AH (1963) Tacaribe virus, a new agent isolated from Artibeus bats and mosquitos in Trinidad, West Indies. American Journal of Tropical Medicine and Hygiene 12:640-646

Alliance E (2019) Infectious disease emergence and economics of altered landscapes (IDEEAL), New York: EcoHealth Alliance/ USAID/RDMA

Ellis BA, Mills JN, Childs JE, Muzzini MC, McKee KT, Enria DA, Glass GE (1997) Structure and floristics of habitats associated with five rodent species in an agroecosystem in Central Ar- 
gentina. Journal of Zoology 243:437-460. https://doi.org/ 10.1111/j.1469-7998.1997.tb02794.x

Enserink M (2000) New Arenavirus blamed for recent deaths in California. Science 289:842-843. https://doi.org/10.1126/science.289.5481.842

Escalera-Antezana JP, Rodriguez-Villena OJ, Arancibia-Alba AW, Alvarado-Arnez LE, Bonilla-Aldana DK, Rodríguez-Morales AJ (2020) Clinical features of fatal cases of Chapare virus hemorrhagic fever originating from rural La Paz, Bolivia, 2019: A cluster analysis. Travel Medicine and Infectious Disease 33:1-6. https://doi.org/10.1016/j.tmaid.2020.101589

Everard M, Johnston P, Santillo D, Staddon C (2020) The role of ecosystems in mitigation and management of Covid-19 and other zoonoses. Environmental Science and Policy 111:7-17. https://doi.org/10.1016/j.envsci.2020.05.017

Fernandes J, de Oliveira RC, Guterres A, de Carvalho Serra F, Bonvicino CR, D'Andrea PS, Cunha RV, Levis S, de Lemos ERS (2015) Co-circulation of Clade C New World Arenaviruses: New geographic distribution and host species. Infection, Genetics and Evolution 33:242-245. https://doi.org/10.1016/j.meegid.2015.05.010

Fernandes J, de Oliveira RC, Guterres A, Barreto-Vieira DF, Terças ACP, Teixeira BR, da Silva MAN, Caldas GC, de Oliveira Coelho JMC, Barth OM, D’Andrea PS, Bonvicino CR, de Lemos ERS (2018) Detection of Latino virus (Arenaviridae: Mammarenavirus) naturally infecting Calomys callidus. Acta Tropica 179:17-24. https://doi.org/10.1016/j.actatropica.2017.12.003

Fernandes J, Guterres A, de Oliveira RC, Jardim R, Dávila AMR, Hewson R, De Lemos ERS (2019) Aporé virus, a novel Mammarenavirus (Bunyavirales: Arenaviridae) related to highly pathogenic virus from South America. Memorias Do Instituto Oswaldo Cruz 114:1-3. https://doi.org/10.1590/007402760180586

Foster ES, Signs KA, Marks DR, et al. (2006) Lymphocytic choriomeningitis in Michigan. Emerging Infectious Diseases Journal 12:851-853. https://doi.org/10.3201/eid1205.050794

Fulhorst CF, Bowen MD, Ksiazek TG, Rollin PE, Nichol ST, Kosoy MY, Peters CJ (1996) Isolation and characterization of Whitewater Arroyo virus, a novel North American Arenavirus. Virology 224:114-120. https://doi.org/10.1006/viro.1996.0512

Fulhorst CF, Bowen MD, Salas RA, de Manzione N, Duno G, Utrera A, Ksiazek TG, Peters CJ, Nichol ST, de Miller E, Tovar D, Ramos B, Vasquez C, Tesh RB (1997) Isolation and characterization of Pirital virus, a newly discovered South American Arenavirus. American Journal of Tropical Medicine and Hygiene 56:548-553

Fulhorst CF, Bennett SG, Milazzo ML, Murray HL, Webb JP, Cajimat NB, Bradley RD (2002) Bear Canyon virus: an Arenavirus naturally associated with the California mouse (Peromyscus californicus). Emerging Infectious Diseases Journal 8:717721

García-Peña GE, Rubio AV, Mendoza H, Fernández M, Milholland MT, Aguirre AA, Suzán G, Zambrana-Torrelio C (2021) Land-use change and rodent-borne diseases: Hazards on the shared socioeconomic pathways. Philosophical Transactions of the Royal Society B Biological Sciences 376:1-11. https://doi.org/ 10.1098/rstb.2020.0362

Geoghegan JL, Duchene S, Holmes EC (2017) Comparative analysis estimates the relative frequence of co-divergence and cross-species transmission within viral families. PLoS Pathogens $13: 1-11$
Geoghegan JL, Senior AM, Di Giallonardo F, Holmes EC (2016) Virological factors that increase the transmissibility of emerging human viruses. Proceedings of the National Academy of Sciences 113:4170-4175. https://doi.org/10.1073/pnas.1521582113

Goldsmith RS, Shields KP (1971) Epidemic in Southern Mexico of disease resembling virus haemorrhagic fevers. Lancet 298(7716):151-154. https://doi.org/10.1016/s0140-6736(71)923 20-8

González J, Emonet S, de Lamballerie X, Charrel RN (2007) Arenaviruses. Current Topics in Microbiology and Inmunology 315:253-288

Greer A, Ng V, Fisman D (2008) Climate change and infectious diseases in North America: the road ahead. Canadian Medical Association Journal 178:715-722

Gubler DJ, Reiter P, Ebi KL, Yap W, Nasci R, Patz JA (2001) Climate variability and change in the United States: potential impacts on vector-and rodent-borne diseases. Environmental Health Perspectives 109:223-233

Han BA, Schmidt JP, Bowden SE, Drake JM (2015) Rodent reservoirs of future zoonotic diseases. Proceeding of National Academy of Sciences 112:7039-7044

Inizan CC, Cajimat MNB, Milazzo ML, Barragán-Gomez A, Bradley RD, Fulhorst CF (2010) Genetic evidence for a Tacaribe serocomplex virus, Mexico. Emerging Infectious Diseases Journal 16:1007-1010. https://doi.org/10.3201/eid1606.091648

Irwin NR, Bayerlová M, Missa O, MartÍnková N (2012) Complex patterns of host switching in New World arenaviruses. Molecular Ecology 21:4137-4150. https://doi.org/10.1111/j.1365294X.2012.05663.x

IUCN (2020) The IUCN Red List of Threatened Species. Version 2020-1. Available:https://www.iucnredlist.org/ [accessed Jun 10, 2020]

Johnson KM, Weibenga NH, Mackensie RB, Kuns ML, Tauraso NM, Shelokov A, Webb PA, Justines G, Beye HK (1963) Virus isolations from human cases of hemorrhagic fever in Bolivia. Proceedings of the Society for Experimental Biology and Medicine 118:113-118

Jones KE, Patel NG, Levy MA, Storeygard A, Balk D, Gittleman JL, Daszak P (2008) Global trends in emerging infectious diseases. Nature 451:990-993. https://doi.org/10.1038/nature06536

Kravetz FE, Percich RE, Zuleta G, Calello MA, Weisembacher MC (1986) Distribution of Junin virus and its reservoirs. A tool for Argentine Hemorrhagic Fever risk evaluation in non-endemic areas. Interciencia 11:185-188

Laenen L, Vergote V, Calisher CH, Klempa B, Klingström J, Kuhn JH, Maes P (2019) Hantaviridae: Current classification and future perspectives. Viruses 11:1-17. https://doi.org/10.3390/ v11090788

Lavergne A, de Thoisy B, Tirera S, Donato D, Bouchier C, Catzeflis F, Lacoste V (2016) Identification of Lymphocytic Choriomeningitis mammarenavirus in house mouse (Mus musculus, Rodentia) in French Guiana. Infection, Genetics and Evolution 37:225-230

Lavergne A, de Thoisy B, Donato D, Guidez A, Matheus S, Catzeflis F, Lacoste V (2015) Patawa virus, a new Arenavirus hosted by forest rodents in French Guiana. Ecohealth 12:339346

Luis AD, O'Shea TJ, Hayman DTS, Wood JLN, Cunningham AA, Gilbert AT, Mills JN, Webb CT (2015) Network analysis of hostvirus communities in bats and rodents reveals determinants of cross-species transmission. Ecology Letters 18:1153-1162. https://doi.org/10.1111/ele.12491 
Mackenzie RB, Beye HK, Valverde L, Garrón H (1964) Epidemic Hemorrhagic Fever in Bolivia I. A Preliminary report of the epidemiologic and clinical findings in a new epidemic area in South America. American Journal of Tropical Medicine and Hygiene 13:620-625

Maroli M, Vadell MV, Padula P, Gómez Villafañe IE (2018) Rodent abundance and Hantavirus infection in protected area, east-central Argentina. Emerging Infectious Diseases Journal 24(1):131-134

Mattar S, Guzmán C, Arrazola J, Soto E, Barrios J, Pini N, Levis S, Salazar-Bravo J, Mills JN (2011) Antibody to arenaviruses in rodents Caribbean Colombia. Emerging Infectious Diseases Journal 17:1315-1317

Mendoza H, Rubio AV, García-Peña GE, Suzán G, Simonetti JA (2020) Does land-use change increase the abundance of zoonotic reservoirs? Rodents say yes European Journal of Wildlife Research 66:1-6. https://doi.org/10.1007/s10344-019-1344-9

Milazzo ML, Cajimat MNB, Haynie ML, Abbott KD, Bradley RD, Fulhorst CF (2008) Diversity among Tacaribe serocomplex viruses (Family Arenaviridae) naturally associated with the white-throated woodrat (Neotoma albigula) in the southwestern United States. Vector-Borne and Zoonotic Diseases 8:523-540

Milazzo ML, Barragán-Gomez A, Hanson JD, Estrada-Franco JG, Arellano E, González-Cózatl FX, Fernández-Salas I, RamirezAguilar F, Rogers DS, Bradley RD, Fulhorst CF (2010) Antibodies to Tacaribe serocomplex viruses (Family Arenaviridae, Genus Arenavirus) in Cricetid rodents from New Mexico, Texas, and Mexico. Vector-Borne and Zoonotic Diseases 10:629637

Milholland MT, Castro-Arellano I, Suzan G, Garcia-Pena GE, Lee TE Jr, Rohde RE, Alonso Aguirre A, Mills JN (2018) Global diversity and distribution of Hantaviruses and their hosts. Ecohealth 15:163-208

Mills JN (2005) Regulation of rodent-borne in the natural host: implications for human disease. In: Peters CJ, Calisher CH (eds) Infectious diseases from nature: mechanisms of viral emergence and persistence, Springer, Viena, pp 45-57. https://doi.org/10. 1007/3-211-29981-5_5

Mills JN, Schmidt K, Ellis BA, Calderón G, Enría DA, Ksiazek TG (2007) A longitudinal study of Hantavirus infection in three sympatric reservoir species in agroecosystems on the Argentine Pampa. Vector-Borne and Zoonotic Diseases 7:229-240

Mills JN, Childs JE (1998) Ecologic studies of rodent reservoirs: Their relevance for human health. Emerging Infectious Diseases 4:529-537

Mills JN, Ellis BA, Ksiazek TG, McKee KT, Maiztegui JI, Childs JE, Peters CJ, Mills JN, Nelson GO, Calderon GE (1992) A longitudinal study of Junin virus activity in the rodent reservoir of Argentine Hemorrhagic Fever. American Journal of Tropical Medicine and Hygiene 47:749-763

Mills JN, Ellis BA, McKee KT, Maiztegui JI, Childs JE (1991) Habitat associations and relative densities of rodent populations in cultivated areas of central Argentina. Journal of Mammalogy 72:470-479. https://doi.org/10.2307/1382129

Moncayo AC, Hice CL, Watts DM, Travassos De Rosa APA, Guzmán H, Russell KL, Calampa C, Gozalo A, Popov VL, Weaver SC, Tesh RB (2001) Allpahuayo virus: a newly recognized Arenavirus (Arenaviridae) from arboreal rice rats (Oecomys bicolor and Oecomys paricola) in northeastern Peru. Virology 284:277-286
Murphy GEP, Romanuk TN (2014) A meta-analysis of declines in local species richness from human disturbances. Ecology and Evolution 4:91-103. https://doi.org/10.1002/ece3.909

PAHO (2021) Fiebres Hemorrágicas. Viral Diseases Available:h ttps://www3.paho.org/hq/index.php?option=com_content\&vie $\mathrm{w}=$ article\&id=8304:2013-fiebre-hemorragica-boliviana\&Itemi $\mathrm{d}=39844$ \&lang=en [accessed Aug 2, 2021]

Pardiñas UFJ, Myers P, León-Paniagua L. Ordóñez, Garza N, Cook JA, Kryštufek B, Haslauer R, Bradley RD, Shenbrot GI, Patton JL (2017) Family Cricetidae (true hamsters, voles, lemmings and New World rats and mice). In: Handbook of the Mammals of the World, Wilson DE, Lacher TE, Mittermeier RA (editors), Barcelona: Lynx Edicions, pp 204-279

Parodi AS, Greenway DJ, Rugiero HR, Frigerio M, De La Barrera JM, Mettler N, Garzon F, Boxaca M, Guerrero L, Nota N (1958) Concerning the epidemic outbreak in Junín. Dia Médico 30:2300-2301

Pinheiro FP, Wooddall JP, Travasos da Rosa APA, Travasos da Rosa JF (1977) Studies in arenaviruses in Brazil. Medicina $37: 175-181$

Polop F, Provensal C, Scavuzzo M, Lamfri M, Calderón G, Polop J (2008) On the relationship between the environmental history and the epidemiological situation of Argentine Hemorrhagic Fever. Ecological Research 23:217-225. https://doi.org/10.1007/ s11284-007-0371-2

Polop J, Calderón G, Feuillade MR, García J, Enria D, Sabattini M (2007) Spatial variation in abundance of the Junin virus hosts in endemic and nonendemic Argentine Haemorrhagic Fever zones. Austral Ecology 32:245-253. https://doi.org/10.1111/j.14429993.2007.01679.x

Prist PR, Prado A, Tambosi LR, et al. (2021) Moving to healthier landscapes: Forest restoration decreases the abundance of Hantavirus reservoir rodents in tropical forests. Science of the Total Environment 752:141967. https://doi.org/10.1016/j.scitotenv.2020.141967

Prist PR, Uriarte M, Tambosi RL, Prado A, Pardini R, D'Andrea PS, Metzger JP (2016) Landscape, environmental and social predictors of Hantavirus risk in São Paulo, Brazil. PLoS One 11:1-18. https://doi.org/10.1371/journal.pone.0163459

QGIS Development Team (2020) QGIS Geographic Information System. Open Source Geospatial Foundation Project

Queen K, Shi M, Anderson LJ, Tong S (2015) Other bat-borne viruses. In: Bats and viruses: a new frontier of emerging infectious diseases, Wang L, Cowled C (editors), New Jersey: John Wiley and Sons, pp 217-247

Radoshitzky SR, Bào Y, Buchmeier MJ, Charrel RN, Clawson AN, Clegg CS, DeRisi JL, Emonet S, Gonzalez JP, Kuhn JH, Lukashevich IS, Peters CJ, Romanowski V, Salvato MS, Stenglein MD, de la Torre JC (2015) Past, present, and future of Arenavirus taxonomy. Archives of Virology 160:1851-1874

Radoshitzky SR, Buchmeier MJ, Charrel RN, Clegg CS, González JP, Gunther S, Hepooki J, Kuhn JH, Lukash IS, Romanowski V, Salvato MS, Sironi M, Stenglein MD, de la Torre J C., ICTV RC (2019) ICTV Virus Taxonomy Profile: Arenaviridae. In: Journal of General Virology. Available: https://talk.ictvonline.org/ictv-re ports/ictv_online_report/negative-sense-rna-viruses/bunyaviral es/w/arenaviridae\#Citation [accessed Jun 23 2020]

Riera L, Castillo E, Saavedra MC, Priotto J, Sottosanti J, Polop J, Ambrosio AM (2005) Serological study of the Lymphochoriomeningitis virus (LCMV) in an Inner City of Argentina. Journal of Medical Virology 76:285-289 
Rubio AV, Ávila-Flores R, Suzán G (2014) Responses of small mammals to habitat fragmentation: Epidemiological considerations for rodent-borne Hantaviruses in the Americas. Ecohealth 11:526-533. https://doi.org/10.1007/s10393-014-0944-9

Sabattini MS, González de Rios LE, Díaz G, Vega VR (1977) Infección natural y experimental de roedores con virus Junin. Medicina (buenos Aires) 37:149-161

Salas R, de Manzione N, Tesh RB, Rico-Hesse R, Shope RE, Betancourt A, Godoy O, Bruzual R, Pacheco ME, Ramos B, Taibo ME, Tamayo JG, Jaimes E, Vasquez C, Araoz F, Querales J (1991) Venezuelan Haemorrhagic Fever. Lancet 338:1033-1036

Sarute N, Ross SR (2017) New World Arenavirus Biology. Annual Review of Virology 4:141-158. https://doi.org/10.1146/annurevvirology-101416-042001

Sayler KA, Barbet AF, Chamberlain C, Clapp WL, Alleman R, Loeb JC, Lednicky JA, Kuhn JH (2014) Isolation of Tacaribe virus, a Caribbean Arenavirus, from host-seeking Amblyomma americanum ticks in Florida. PLoS One 9:1-16. https://doi.org/ 10.1371/journal.pone.0115769

Shi M, Lin XD, Chen X, Tian JH, Chen LJ, Li K, Wang W, Eden JS, Shen JJ, Liu L, Holmes EC, Zhang YZ (2018) The evolutionary history of vertebrate RNA viruses. Nature 556:197-202. https://doi.org/10.1038/s41586-018-0012-7

Shipley R, Wright E, Selden D, Wu G, Aegerter J, Fooks AR, Banyard AC (2019) Bats and viruses: Emergence of novel Lyssaviruses and association of bats with viral zoonoses in the EU. Tropical Medicine and Infectious Disease 4:1-22. https://doi.org/ 10.3390/tropicalmed4010031

Suzán G, Marcé E, Giermakowski JT, Armién B, Pascale J, Mills J, Ceballos G, Gómez A, Aguirre AA, Salazar-Bravo J, Armién A, Parmenter R, Yates T (2008) The effect of habitat fragmentation and species diversity loss on Hantavirus prevalence in Panama. Annals of the New York Academy of Sciences 1149:80-83. https:// doi.org/10.1196/annals.1428.063

Taylor LH, Latham SM, Woolhouse MEJ (2001) Risk factors for human disease emergence. Philosophical Transactions of the Royal Society B Biological Sciences 356:983-989

Ter Meulen J, Lukashevich I, Sidibe K, Inapogui A, Marx M, Dorlemann A, Yansane ML, Koulemou K, Chang-Claude J,
Schmitz H (1996) Hunting of peridomestic rodents and consumption of their meat as possible risk factors for rodent-tohuman transmission of Lassa virus in the Republic of Guinea. American Journal of Tropical Medicine and Hygiene 55:661-666. https://doi.org/10.4269/ajtmh.1996.55.661

Tian H, Stenseth NC (2019) The ecological dynamics of Hantavirus diseases: from environmental variability to disease prevention largely based on data from China. PLoS Neglected Tropical Diseases 13:1-19. https://doi.org/10.1371/journal.pntd.0006901

Trapido H, Sanmartin C (1971) Pichindé virus, a new virus of the Tacaribe group from Colombia. American Journal of Tropical Medicine and Hygiene 20:631-641

Utrera A, Duno G (2007) Preferencias de hábitat de Sigmodon alstoni y Zygodontomys brevicauda (Rodentia, Cricetidae) en agroecosistemas de los Llanos de Venezuela. Interciencia 32:471476

Vitullo AD, Merani MS (1988) Is vertical transmission sufficient to maintain Junin virus in nature? Journal of General Virology 69(Pt6):1437-1440. https://doi.org/10.1099/0022-1317-69-61437

Webb PA, Johnson KM, Hibbs JB, Kuns ML (1970) Parana, a new Tacaribe complex virus from Paraguay. Arch Gesamte Virusforsch 32:379-388

Webb PA, Johnson KM, Peters CJ, Justines G (1973) Behavior of Machupo and Latino viruses in Calomys callosus from two geographic areas of Bolivia. In: Lymphocytic Choriomeningitis virus and other Arenaviruses, Lehmann-Grube F (editor), Berlin: Springer, pp 313-322 . 10.1007/978-3-642-65681-1_27

Yates TL, Mills JN, Parmenter CA, Ksiazek TG, Parmenter RR, Vande Castle JR, Calisher CH, Nichol ST, Abbott KD, Young JC, Morrison ML, Beaty BJ, Dunnum JL, Baker RJ, SalazarBravo J, Peters CJ (2002) The ecology and evolutionary history of an emergent disease: hantavirus pulmonary syndrome. Bioscience 52:989-998. https://doi.org/10.1641/00063568(2002)052[0989:teaeho]2.0.co;2

Zapata JC, Salvato MS (2013) Arenavirus variations due to hostspecific adaptation. Viruses 5:241-278. https://doi.org/10.3390/ v5010241 